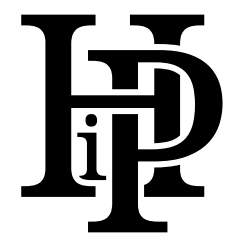

Marzena MRUK

Uniwersytet Śląski, Wydział Nauk Społecznych, Katowice, Polska

\title{
Muzułmanie w Szwecji w XXI wieku - między asymilacją a radykalizacją
}

\author{
Muslims in Sweden in the $21^{\text {st }}$ Century: Between Assimilation and Radicalization
}

\section{- Abstrakt •}

Problem asymilacji społeczności muzułmańskiej w krajach europejskich stanowi jedno z najważniejszych wyzwań dla rządów oraz rdzennych obywateli państw, które od lat poddawane są procesowi globalizacji, a tym samym masowym migracjom ludności, co przyczynia się do zachwiania struktur społecznych. Współczesna Szwecja jest jednym z państw, które jest wybierane jako kierunek migracji społeczności muzułmańskiej z państw Afryki i Bliskiego Wschodu, co wiąże się z wieloma nowymi wyzwaniami, takimi jak kwestia radykalizacji mniejszości czy też próby dostosowania nowo przybyłych imigrantów do obowiązującego w państwie porządku społeczno-prawnego.

Niniejszy artykuł ma na celu nakreślenie czytelnikowi problematyki asymilacji mniejszości muzułmańskiej w Szwecji w XXI wieku oraz wzrastającej radykalizacji wyznawców islamu poprzez omówienie kluczowych dla zrozumienia tej problematyki zagadnień, czyli charakterystyki ludności muzułmańskiej w Szwecji, kwestii wzrastającego fundamentalizmu islamskiego, problemu integracji społeczności islamskiej z rodowitymi Szwedami, oraz omówienie kryzysu migracyjnego w 2015 roku.

\section{- Abstract •}

The problem of assimilation of the Muslim community in Western countries is one of the most important challenges for the governments and indigenous citizens of countries that have been subject to the process of globalization for years, and thus mass migration of people, which contributes to the disruption of social structures. Contemporary Sweden is one of the countries chosen as the destination of migration for the Muslim community from the countries of Africa and the Middle East, which is associated with many new challenges, such as the issue of radicalization of minorities or attempts to adapt new immigrants to the socio-legal order in force in the country.

This article aims to outline to the reader the issues of assimilation of the Muslim minority in Sweden in the $21^{\text {st }}$ century and the increasing radicalization of Muslims, by discussing the key issues for understanding this matter, i.e., the characteristics of the Muslim population in Sweden, the issue of growing Islamic fundamentalism, the problem of integration of the Islamic community with native Swedes, as well as discussing the migration crisis of 2015 . 
Słowa kluczowe: Szwecja; migracja; asymilacja; radykalizacja
Keywords: Sweden; migration; assimilation; radicalization

\section{Wstęp}

Problematyka asymilacji imigrantów we współczesnym świecie stanowi wyzwanie dla rządów państw, ale także dla ich rodowitych mieszkańców. Wzrost znaczenia globalizacji, a co za tym idzie - proces imigracji zmieniły współczesną Szwecję w państwo pluralistyczne pod względem etnicznym, ale przede wszystkim wyznaniowym. Szwecja pozostaje państwem silnie świeckim, posiada ogromne dziedzictwo luterańskie, co przejawia się znaczną liczbą budynków sakralnych na terytorium całego kraju. Sprawia to wrażenie, że mamy do czynienia z państwem bardzo związanym z religią. Niemniej Szwecja jest określana jako jedno z najbardziej świeckich państw na świecie (Elander i in., 2015, s. 151-152). Jest to o tyle zaskakujące, że faktyczny rozdział religii od państwa zaczął w Szwecji funkcjonować dopiero od 2000 roku, co skutkowało tym, że wyznawcy każdej religii są traktowani w równy sposób.

Szwecja w dyskursie publicznym określana jest często jako idealny kierunek dla migrantów, szczególnie z rozwijających się państw muzułmańskich Afryki Północnej i Bliskiego Wschodu. Powoduje to, że zróżnicowanie społeczeństwa jest na bardzo wysokim poziomie, co z kolei warunkuje różnego rodzaju problemy i wyzwania związane z utrzymaniem stabilnej sytuacji wewnątrz kraju. Rosnąca radykalizacja i problemy z integracją ze społeczeństwem szwedzkich muzułmanów, szczególnie w drugim, a nawet trzecim pokoleniu potomków imigrantów, stały się nie tylko obiektem zainteresowania naukowców z całego świata, ale także inspiracją dla twórców kultury masowej, w tym filmów i seriali, które stanowią źródło poglądowe dla wielu osób, które dotychczas nie zwracały uwagi na ten problem, i wskazują, jak może wyglądać droga do radykalizacji przeciętnego szwedzkiego obywatela muzułmańskiego pochodzenia. Ważne w zrozumieniu tak skomplikowanego i złożonego procesu jest poznanie powodów, dla których mniejszość muzułmańska w Szwecji funkcjonuje w zamkniętych społecznościach i ogranicza swoje kontakty z rodowitymi obywatelami tego państwa do koniecznego minimum, oraz wskazanie, jak rząd szwedzki stara się koordynować proces integracji mniejszości ze społeczeństwem i z jakim skutkiem.

Artykuł przedstawia wybrane zagadnienia dotyczące obecności mniejszości muzułmańskiej w Szwecji, takie jak: charakterystyka wyznawców islamu w tym państwie, procesy radykalizacji w XXI wieku, problemy z asymilacją, oraz proble- 
matykę wpływu kryzysu migracyjnego z 2015 roku na sytuację w Szwecji, co odpowiada podziałowi artykułu na cztery części. Podstawową tezą artykułu jest stwierdzenie, że Szwecja jak każde państwo wieloetniczne i wielowyznaniowe mierzy się z problemami asymilacyjnymi oraz rosnącym radykalizmem. Autor będzie się starał odpowiedzieć na szereg pytań badawczych, takich jak: w jaki sposób przejawiała się radykalizacja muzułmanów w Szwecji w XXI wieku? Z jakimi problemami związanymi z asymilacją muzułmanów ze społeczeństwem musiały się zmagać władze Szwecji? Jak rząd Szwecji zareagował na kryzys migracyjny w 2015 roku? Czy wzrost liczby muzułmanów w Szwecji przyczynia się do nastrojów islamofobicznych wśród społeczeństwa? Do analizy przyjętego problemu zostały wykorzystane następujące metody badawcze: analiza historyczna, metoda decyzyjna, synteza oraz analiza i krytyka piśmiennictwa i źródeł. W pracy zostały wykorzystane źródła polskojęzyczne oraz liczne anglojęzyczne pozycje naukowe.

\section{Charakterystyka społeczności muzułmańskiej w Szwecji}

Społeczność muzułmańska zamieszkująca Szwecję nie należy do jednolitych, gdyż oprócz klasycznego podziału na szyitów i sunnitów występuje również duże zróżnicowanie narodowościowe, które obejmuje muzułmanów pochodzących zarówno z państw afrykańskich, jak i Bliskiego i Środkowego Wschodu. Wśród państw, z których pochodzą muzułmanie zamieszkujący Szwecję, najczęściej wymieniane są następujące kraje: Irak (w tym jedna trzecia to Kurdowie), Liban, Maroko, Syria, Tunezja i Palestyna - stanowią jedną trzecią wszystkich muzułmanów w Szwecji, czyli około 53 tys.; Iran - około 50 tys.; Turcja - jedna dziesiąta wszystkich muzułmanów; państwa bałkańskie, Pakistan, Somalia i inne (Woźniak, 2012, s. 232). W Szwecji występuje problem z oszacowaniem liczby muzułmanów zamieszkujących ten kraj. Ostatni spis powszechny, w którym należało określić swoje wyznanie, przeprowadzono w 1930 roku (Gromkowska-Melosik, 2013, s. 65). Obecnie szacuje się, że blisko 8\% ludzi zamieszkujących Szwecję to muzułmanie, czyli w przybliżeniu 400-450 tys. osób. Należy jednak mieć na uwadze, że liczba ta od lat wzrasta. W 2016 roku oszacowano, że Szwecja jest trzecim państwem Unii Europejskiej, zaraz po Bułgarii i Francji, pod względem liczby mieszkańców wyznających islam (Abdullahi, Hübinette, 2018, s. 10). Zdecydowana większość muzułmanów w Szwecji zamieszkuje trzy miasta: Sztokholm, Malmö i Göteborg (Kosmynka, 2020, s. 120). Wskazuje się, że Malmö, a w szczególności jego dzielnica Rosengård, jest obszarem prawie jednolitym etnicznie, a to znaczy, że zdominowana jest przez ludność muzułmańską, z kolei Göteborg zamieszkuje 20\% mu- 
zułmanów. Tworzenie się tak dużych enklaw muzułmańskich w najważniejszych szwedzkich miastach spowodowało, że imam Adly Abu Hajar określił Szwecję jako „najlepsze państwo islamskie na świecie” (Gromkowska-Melosik, 2013, s. 64-66).

Wśród głównych przesłanek decydujących o imigracji ludności muzułmańskiej do Szwecji podaje się przede wszystkim względy ekonomiczne, czyli emigrację o charakterze zarobkowym, oraz korzyści związane z osiedleniem się w opiekuńczym państwie dobrobytu (tzw. welfare state). Drugą przesłanką jest natomiast chęć uzyskania statusu uchodźcy politycznego, gdyż kreowana od lat przez szwedzki rząd polityka otwartości stanowi dla wielu symbol pomocy dla osób prześladowanych politycznie (Gromkowska-Melosik, 2013, s. 66). Aby dobrze zrozumieć politykę Szwecji wobec mniejszości muzułmańskiej, należy najpierw skupić się na powstałej w latach 20. XX wieku dzięki Szwedzkiej Socjaldemokratycznej Partii Robotniczej idei „Domu dla ludzi”. Według tej koncepcji państwo miało mieć na celu zapewnienie każdemu obywatelowi opieki, równych szans rozwoju oraz dostatniego życia, co bardzo dobrze wpisywało się w okres szybkiego wzrostu postępu przemysłowego i technologicznego w Szwecji (Gromkowska-Melosik, 2013, s. 68).

Szwedzka Komisja ds. Dotacji Państwowych dla Wspólnot Religijnych wielokrotnie wskazywała, że jedna trzecia szwedzkich muzułmanów to grupa ściśle przestrzegająca prawa islamskiego, a pozostali są z reguły zsekularyzowani, co oznacza, że nie przestrzegają prawa szariatu oraz uznają rozdział państwa od religii. Różnice są także zauważalne w podejściu poszczególnych pokoleń do funkcjonowania w grupach etnicznych. O ile wcześniejsze pokolenia koncentrowały się na utrzymaniu tożsamości etnicznej dzięki podtrzymywaniu kontaktu z imigrantami ze swojego kraju pochodzenia, o tyle najmłodsze pokolenie muzułmanów jest zdecydowanie bardziej elastyczne pod tym względem i dąży do podtrzymania tożsamości muzułmańskiej jako ogółu wyznawców islamu (Larsson, 2007, s. 14-16). To powoduje, że muzułmańska młodzież jest zdecydowanie lepiej zintegrowana ze swoimi rówieśnikami wyznającymi islam, niezależnie od kraju pochodzenia, niż jej rodzice.

\section{Wzrost radykalizmu islamskiego}

Szwecja jak każde państwo zamieszkałe przez mniejszości religijne musi się mierzyć z problemem radykalizacji oraz integracji poszczególnych grup ze swoim społeczeństwem. Problem ten można szczególnie zauważyć od początku XXI wieku, gdy w wyniku wzrostu aktywności islamskich organizacji terrorystycznych na świecie muzułmanie w Szwecji zaczęli ulegać wpływom radykalnych islamskich duchow- 
nych wzywających do walki z Zachodem i nieintegrowania się ze społeczeństwem. Za przykład uznaje się to, że w Göteborgu ekstremiści islamscy namawiali mieszkających w mieście muzułmanów do bojkotu wyborów lokalnych, które uznali za niezgodne z nauką islamu, a sam Göteborg określono jako stolicę wahhabizmu w Europie (Kosmynka, 2020, s. 121).

Wzrost ekstremizmu islamskiego w Szwecji odnotowano po atakach z 11 września 2001 roku. Szwedzka policja ustaliła, że w kraju funkcjonują małe grupy zwolenników Al-Kaidy, którzy wcześniej uczęszczali do fundamentalistycznych szkół koranicznych w Arabii Saudyjskiej i Jemenie. Wielu szwedzkich muzułmanów brało udział w działaniach wojennych w Iraku (m.in. Muhammad Moumou, określany także jako Abu Kasuarah al-Maghribi) czy prowadziło obozy szkoleniowe dla dżihadystów (np. Osama Kassir - szwedzki muzułmanin pochodzenia libańskiego, który próbował w Oregonie w Stanach Zjednoczonych utworzyć obóz szkoleniowy dla dżihadystów; Kosmynka, 2020, s. 122-123). Szacuje się, że w latach 2006-2009 blisko 300 Szwedów pochodzenia somalijskiego dołączyło do somalijskiej organizacji Asz-Szabab (Sturup i in., 2020, s. 393).

Od 2008 roku Szwecja stała się miejscem, w którym zaczęło dochodzić do brutalizacji zachowań radykalnych muzułmanów, którzy zaczęli dopuszczać się liczniejszych ataków na rodowitych Szwedów oraz ich dobra materialne. Od tego czasu szwedzka policja odnotowuje zwiększoną liczbę podpaleń samochodów należących do Szwedów zamieszkujących niemuzułmańskie dzielnice dużych miast oraz ataki z wykorzystaniem bomb i granatów, którymi atakowane są szwedzkie sklepy czy miejsca użyteczności publicznej. W grudniu 2010 roku Irakijczyk zamieszkujący Szwecję dokonał samobójczej detonacji w centrum Sztokholmu, natomiast w 2011 roku szwedzka policja zatrzymała grupę islamskich radykałów, którzy planowali zamach na Larsa Vilksa, który był autorem karykatury postaci Mahometa (Kosmynka, 2020, s. 123). Ponadto Szwedzi od kilkunastu lat są ofiarami tzw. polityki ruchomych granic, która polega na zastraszaniu mieszkańców danego obszaru, tak by opuścili oni swoje miejsca zamieszkania, które w następstwie tego są zamieszkiwane przez rodziny muzułmańskie (Michalak, 2017, s. 292-293).

Problem z radykalizacją szwedzkich muzułmanów zaczął nabierać tempa, gdy w czerwcu 2014 roku ogłoszono powstanie tzw. Państwa Islamskiego w Syrii i Iraku. W samym mieście Göteborg samozwańczy kalifat zrekrutował około 100 mężczyzn do wejścia w struktury organizacji. W 2016 roku oszacowano, że ponad 300 bojowników Państwa Islamskiego pochodzi ze Szwecji, a ponad 140 wróciło do Europy. Ponadto około $75 \%$ z nich posiadało szwedzkie obywatelstwo, a ponad 30\% urodziło się w Szwecji (Kosmynka, 2020, s. 120-124). 
Według Międzynarodowego Centrum Zwalczania Terroryzmu Szwecja, zaraz po Belgii i Austrii, jest jednym z państw o największej liczbie zagranicznych bojowników na jednego mieszkańca. W ostatnich latach Europol informował, że wzrasta liczba osób powracających z obszarów objętych działaniami zbrojnymi, przede wszystkim do Holandii, Niemiec i Szwecji. Szwedzkie Narodowe Centrum Oceny Zagrożeń Terrorystycznych w swoim raporcie ogłosiło, że zagrożenie terrorystyczne dla Szwecji wynika głównie z radykalnych islamskich ideologii promujących przemoc (Sturup i in., 2020, s. 383). Służby bezpieczeństwa w Szwecji oszacowały profil mieszkańca tego kraju, który zdecydował się na wyjazd do Iraku lub Syrii. Wskazuje się, że byli to w większości młodzi mężczyźni w przedziale wiekowym 18-30 lat, urodzeni w Szwecji, przy czym co najmniej jeden z ich rodziców jest cudzoziemcem. Wielu z nich to osoby bezrobotne lub o bardzo niskim dochodzie. Bojownicy, którzy zdecydowali się wrócić do Szwecji, posiadają doświadczenie w prowadzeniu działań bojowych i nadal wierzą w ideologię kreowaną przez Państwo Islamskie (Sturup i in., 2020, s. 384-385).

Szwecja stara się od kilkunastu lat reagować na zagrożenia terrorystyczne, szczególnie w kontekście kształtowania nowego prawa antyterrorystycznego. W 2010 roku uznano za przestępstwo rekrutację do organizacji terrorystycznej oraz udział w szkoleniu członków takiej organizacji. W 2016 roku wprowadzono zakaz wyjazdu z kraju z zamiarem wstąpienia do organizacji islamistycznych podejrzewanych o działalność terrorystyczną. W 2019 roku poszerzono uprawnienia służb, które uzyskały prawo do kontroli cudzoziemców, w tym prawo do zatrzymania i deportacji osób podejrzanych, nawet jeśli zostały one uniewinnione przez szwedzki sąd z zarzutów o działalność terrorystyczną (Mulinari, 2019, s. 453).

\section{Problemy z integracją muzułmanów w Szwecji}

$\mathrm{Na}$ radykalizację szwedzkich muzułmanów wpływają przede wszystkim ich problemy z integracją z autochtonami. Różnice występujące między rodowitymi Szwedami a ludnością wyznającą islam bywają na tyle duże, że uniemożliwiają podjęcie jakiejkolwiek formy dialogu między stronami, a to z kolei powoduje narastanie antagonizmów społecznych i poczucia wzajemnej nieufności.

Szwecja jest państwem, w którym występują znaczące różnice w postrzeganiu wielokulturowości między rodowitymi Szwedami a ludnością muzułmańską. Dla Szwedów wielokulturowość oznacza równość wszystkich ludzi, niezależnie od płci, rasy, wyznania, pochodzenia etnicznego czy kultury, a wszelkie różnice kulturowe czy religijne powinny ograniczać się wyłącznie do danego gospodarstwa domowe- 
go. Mniejszość islamska uważa z kolei, że wielokulturowość to prawo do wolności wyznania i życia zgodnie z własną kulturą, co skutkuje tym, że dążą oni do uznania ich praw kulturowych i religijnych oraz prawa ich eksponowania w przestrzeni publicznej. Podobnie sprawa wygląda w kwestii podejścia do wychowywania dzieci. Szwedzka wolność w sferze seksualnej oraz idea wolności młodzieży jest całkowicie nie do zaakceptowania przez mniejszość islamską, która uznaje je za niezgodne z prawem islamskim. Powoduje to, że muzułmanie ograniczają możliwości kontaktu swoich dzieci z ich szwedzkimi rówieśnikami, których zachowanie uznają za zepsute i niemoralne (Gromkowska-Melosik, 2013, s. 69-70). Szacuje się, że blisko 60\% dzieci imigrantów muzułmańskich w Szwecji nie kończy swojej edukacji na poziomie szkół podstawowych, co w konsekwencji sprawia, że jako osoby dorosłe są one zmuszone podjąć niskopłatne prace. Należy jednak pamiętać, że i w tym zakresie istnieją rozbieżności wśród mniejszości muzułmańskiej, ponieważ wskazuje się, że mniejszość islamska pochodzenia irańskiego zamieszkująca Szwecję na ogół jest dobrze wykształcona i odnajduje się na rynku pracy (Larsson, 2007, s. 7). Rząd Szwecji w 1992 roku wyszedł naprzeciw muzułmańskim rodzicom i wydał zgodę na tworzenie niezależnych szkół islamskich, które miały przyczynić się do zachowania islamskiej tożsamości wśród dzieci imigrantów, natomiast w kilku szkołach publicznych wycofano z oferty stołówek wieprzowinę, tak by nie razić uczuć religijnych muzułmańskich dzieci (Gromkowska-Melosik, 2013, s. 74).

Problem znajomości języka szwedzkiego przez imigrantów jest aktualny nieustannie od 1980 roku, gdy oficjalnie stwierdzono, że znajomość tego języka przestaje być wymagana w celu osiedlenia się w Szwecji. Powoduje to, że rodowici Szwedzi coraz częściej wyrażają swoje niezadowolenie z bariery językowej, która występuje między nimi a ludnością muzułmańską. Ponadto skutkuje to tym, że Szwedzi zaczynają odbierać muzułmanów jako grupę gorszych przedstawicieli swojego społeczeństwa, nawet jeśli posiadają oni szwedzkie obywatelstwo (Gromkowska-Melosik, 2013, s. 71).

W światowej kulturze popularnej dostępnej w Szwecji można zauważyć promowanie stereotypów dotyczących statusu płci w islamie, które przedstawiają muzułmańskich mężczyzn w sposób negatywny, podkreślając ich zaangażowanie w działania przemocowe wobec kobiet. $Z$ kolei muzułmanki są utożsamiane z postaciami uciskanymi przez religię i mężczyzn oraz z ofiarami przemocy (Bevelander, Otterbeck, 2007, s. 10). Od 2015 roku w Szwecji zaczęła wzrastać liczba gwałtów na kobietach, w wyniku czego kraj ten stał się państwem z największym współczynnikiem gwałtów w Europie. Statystyki policyjne w Szwecji jasno określiły, że imigranci stanowili oko 90\% sprawców, z czego 77\% to muzułmanie. Raport Krajowej Rady Zapobiegania Przestępczości z listopada 2016 roku wskazał, że liczba 
wszystkich przestępstw na tle seksualnym wobec kobiet w Szwecji wzrosła w ciągu dwóch lat (od 2013 do 2015 roku) z 1,5\% do 2,4\%. Ponadto coraz częstsza zaczęła się stawać praktyka określana jako taharush, która polegała na zbiorowym znęcaniu się, molestowaniu i gwałtach dokonywanych przez dużą grupę mężczyzn na kobietach. Do takich sytuacji doszło m.in. w 2014 i 2015 roku w czasie jednego z festiwali młodzieżowych oraz w noc sylwestrową 2015 roku. Codziennością stał się także proceder molestowania szwedzkich nastolatek i kobiet na basenach (Michalak, 2017, s. 297).

Szwecja od początku XXI wieku doświadcza zjawiska konwersji na islam. W porównaniu z innymi państwami europejskimi praktyka ta jest w Szwecji na stosunkowo niskim poziomie. Wśród przyczyn dokonywania konwersji na islam wskazuje się przede wszystkim zawarcie związku małżeńskiego z wyznawcą islamu (kobiety) oraz uznanie, że islam dostarcza o wiele bardziej wartościowe zasady i przepisy niż te, które obowiązują w Szwecji, a także indoktrynacja organizacji fundamentalistycznych, szczególnie wśród osób młodych szukających swojej drogi życiowej (mężczyźni; Larsson, 2007, s. 17).

Wyzwaniem dla szwedzkich służb bezpieczeństwa, szczególnie policji, jest kwestia wzrastającej liczby obszarów, w których za jedyny system prawny i polityczny uznaje się prawo szariatu, a liczba no-go zone wynosi ponad $60 \mathrm{w}$ całej Szwecji (Michalak, 2017, s. 294). W grudniu 2015 roku grupa salafitów ogłosiła, że prawo islamskie jest prawem obowiązującym w Szwecji, oraz wyszła ze swoistą ofertą do niewiernych w jednym ze szwedzkich miast. W miejscowości Märsta islamiści rozpoczęli kampanię ulotkową (opatrzoną flagą Państwa Islamskiego), podczas której zaoferowano niemuzułmanom trzy opcje do wyboru: przejście na islam, zapłatę dżizji lub śmierć (Michalak, 2017, s. 297).

W lipcu 2015 roku ujawniono, że jedna z pracownic szwedzkiej agencji rządowej odpowiedzialnej za politykę imigracyjną wyraża się w sposób pozytywny wobec tzw. Państwa Islamskiego i pomimo swojego oficjalnego wsparcia dla organizacji terrorystycznej nie straciła stanowiska. Z kolei w 2016 roku jedna z przedstawicielek szwedzkiej prokuratury uznała, że na terenie Szwecji flaga tzw. Państwa Islamskiego jest legalna, gdyż ,nie jest to organizacja rasistowska”, a władze miasta Lund zapowiedziały program resocjalizacji i reintegracji dla szwedzkich bojowników kalifatu powracających do kraju, który miał obejmować: opłacenie kursu prawa jazdy, pomoc w znalezieniu mieszkania, obniżenie podatków i opłat administracyjnych. Takie deklaracje przedstawicieli szwedzkich władz spowodowały, że poziom nieufności do muzułmanów wśród Szwedów zaczął wzrastać, szczególnie że jeden z głównych ekspertów ds. terroryzmu, Magnus Ranstorp, ogłosił, że co najmniej dwóch szwedzkich dżihadystów było związanych z atakami terrorystycz- 
nymi w Paryżu w 2015 i w Brukseli w 2016 roku (Michalak, 2017, s. 299). Ponadto muzułmanie w Szwecji borykają się z problemem braku reprezentacji na szwedzkiej arenie politycznej (z wyjątkiem Nalina Pekgula czy Mehmeta Kapłana). Powoduje to, że w Szwecji dochodzi do sytuacji dość dziwnej, kiedy to muzułmanie wyznający radykalne zasady i wartości, które odpowiadają raczej partiom prawicowym, w wyborach głosują na partie lewicowe (Woźniak, 2012, s. 233) lub zaczynają zwracać się w kierunku radykalnych muzułmańskich organizacji, które oferują im stworzenie w Szwecji nowego państwa opartego na prawie szariatu.

Należy pamiętać, że aby zintegrować każdą mniejszość z dominującą grupą społeczną pod względem politycznym, społecznym, ekonomicznym i kulturowym, potrzeba czasu. Ponadto osoby o muzułmańskim pochodzeniu mają tendencję do traktowania swojej islamskiej tożsamości jako kluczowej i ważniejszej od tej występującej w danym kraju. Zamknięcie się na integrację powoduje, że mniejszości mogą odczuwać utrudnienia w życiu codziennym.

\section{Szwecja a kryzys migracyjny}

Anne Sofie Roald opisała trzy główne fale imigracji do Szwecji. Pierwsza z nich miała miejsce po II wojnie światowej i obejmowała głównie tureckich Tatarów. Druga fala nastąpiła w latach 60. XX wieku, a w jej skład wchodzili obywatele Jugosławii, Turcji i Pakistanu. Trzecia fala była datowana na lata 80. XX wieku i składała się z uchodźców politycznych z Iraku, Iranu, Libanu oraz Kurdów (Gromkowska-Melosik, 2013, s. 66). Niemniej kluczową rolę w ostatnich latach odegrał kryzys migracyjny z 2015 roku, który można uznać za czwartą falę imigracji do Szwecji. Wydarzenia Arabskiej Wiosny, do jakich zaczęło dochodzić na początku drugiej dekady XXI wieku w państwach Afryki Północnej oraz Bliskiego Wschodu, a w ich konsekwencji konflikty zbrojne w Syrii, Iraku, Jemenie czy Afganistanie przyczyniły się do tego, że od 2015 roku państwa Unii Europejskiej, w tym Szwecja, zostały przytłoczone słabo kontrolowanymi falami migracji ludności muzułmańskiej.

W 2014 roku przeprowadzono badania mające na celu określenie stosunku mieszkańców Szwecji do procesu imigracji oraz imigrantów. Blisko 72\% Szwedów wykazało pozytywne nastawienie wobec imigrantów spoza obszaru Unii Europejskiej, a 82\% wobec migracji w ramach Wspólnoty (Kobieracka, 2016, s. 131). Jeszcze w 2014 roku zakładano, że w wyniku zmieniającej się sytuacji międzynarodowej na Bliskim Wschodzie i w Afryce Północnej w następnym roku Szwecję może czekać fala migracji obejmująca około 100 tys. osób. Nie zakładano, że proces mi- 
gracji osiągnie tak duże rozmiary i już w październiku 2015 roku szwedzka Agencja ds. Migracji wskazała, że należy spodziewać się 190 tys. osób ubiegających się o azyl w tym państwie, w tym duży odsetek osób nieletnich pozbawionych opieki rodziców (Zawadzki, 2016, s. 86). Według oficjalnych statystyk rządu szwedzkiego dopiero w 2016 roku władze zarejestrowały i wydały ponad 162 tys. zezwoleń na pobyt na terytorium Szwecji, z czego $80 \%$ pozwoleń obejmowała grupę muzułmanów, którzy przybyli wraz z falą migracyjną w 2015 roku (Eidemiller i in., 2018, s. 3).

Należy wskazać, że znaczącą kwestią związaną z kryzysem migracyjnym była wojna domowa w Syrii. Na długo przed rozpoczęciem się konfliktu wielu Syryjczyków ubiegało się o azyl w Szwecji, lecz nie na taką skalę, jaka była widoczna od 2015 roku, kiedy to liczba Syryjczyków ubiegających się o pozwolenie pobytu wyniosła prawie 52 tys. Spowodowało to, że Szwecja obok Niemiec stała się głównym kierunkiem migracji tej nacji. Uczyniło to Syryjczyków jedną z największych grup imigrantów w Szwecji - stanowili oni 1,48\% całkowitej populacji tego państwa. Pod względem demograficznym większość, czyli 64\%, Syryjczyków ubiegających się o azyl w Szwecji w latach 2010-2017 stanowili mężczyźni, a 32\% to osoby nieletnie (Eurostat, 2016, s. 5). Warto zwrócić także uwagę na uwarunkowania, które zdecydowały, że Syryjczycy wybrali Szwecję jako kierunek docelowy ucieczki. Szwecja uznawana jest za państwo przyjazne dla cudzoziemców, szczególnie z obszarów objętych działaniami zbrojnymi, czego przykładem jest przyjęcie przez Szwecję na przestrzeni lat uchodźców z Bośni, Afganistanu, Iraku czy Somalii. Uznaje się, że Szwecja była państwem z największą liczbą imigrantów przypadających na jednego mieszkańca wśród państw Unii Europejskiej. Wynikało to z faktu, że automatyczne pozwolenie na pobyt stały otrzymywały wszystkie osoby deklarujące się jako Syryjczycy uciekający przed wojną domową, podczas gdy inne państwa zdecydowały się na przyjęcie obywateli Syrii pod warunkiem, że gdy sytuacja w tym państwie się ustabilizuje, zostaną odesłani do ojczyzny. Ponadto Syryjczycy starali się wykorzystywać prawo łączenia rodzin, co spowodowało masowy napływ kolejnych osób, którym rząd szwedzki musiał zapewnić pomoc (Zawadzki, 2016, s. 98-99).

Szwecja w związku z tak ogromną liczbą imigrantów zmuszona była do wprowadzenia w listopadzie 2015 roku licznych ograniczeń. 12 listopada wprowadzono pojęcie tymczasowych granic i kontroli tożsamości osób przybywających do Szwecji pociągiem, autobusem lub statkiem. Był to pierwszy raz od 1995 roku, gdy Szwecja przystąpiła do układu z Schengen. Osoby przybywające do Szwecji musiały natychmiast ubiegać się o przyznanie statusu azylanta, co uniemożliwiało im deportację. 24 listopada 2015 roku rząd Szwecji ogłosił, że osoby ubiegające się o azyl 
mogą uzyskać tylko tymczasowe pozwolenie na pobyt w Szwecji. Niespotykana dotychczas skala napływu imigrantów do Szwecji, którzy ubiegali się o status azylanta, przyczyniła się do przedłużenia procedur biurokratycznych oraz skutkowała problemami z udzieleniem koniecznej i podstawowej pomocy dla nowo przybyłych osób, przede wszystkim schronienia, podstawowych środków do życia czy opieki lekarskiej (Zawadzki, 2016, s. 97).

Warto zadać pytanie, dlaczego Szwecja zdecydowała się na taką otwartą politykę wobec imigrantów podczas kryzysu migracyjnego, pomijając kwestie prawa humanitarnego oraz chęć udzielania pomocy. Szwecja postrzega migrantów przybywających do tego kraju przede wszystkim jako potencjalne cenne dobro gospodarcze i siłę roboczą, która może przyczynić się do wzrostu gospodarczego. Wskazuje się, że Szwecja potrzebuje około 64 tys. imigrantów rocznie, jeśli chce zapobiec spadkowi rozwoju ekonomicznego oraz zahamowaniu niedoborów siły roboczej (Brljavac, 2017, s. 98).

\section{Wnioski}

Wzrost liczby muzułmanów w Szwecji powoduje, że od kilku lat można zauważyć swoistą nostalgię i tęsknotę za czystym etnicznie krajem. Szwedzi zaczynają podkreślać, że imigranci muzułmańscy chętnie korzystają z dobrodziejstw szwedzkiego systemu opieki społecznej, w zamian wnosząc do społeczeństwa szwedzkiego pogłębiające się różnice (przede wszystkim ideologiczne i ekonomiczne) oraz obniżając poziom życia rodowitych Szwedów (Gromkowska-Melosik, 2013, s. 70). Problemem jest także wzrastający antysemityzm na obszarach zamieszkiwanych przez muzułmanów, gdzie wielokrotnie dochodziło do ataków na Żydów czy synagogi. Spowodowało to, że Szwecja znalazła się na skraju konfliktu dyplomatycznego z Izraelem, szczególnie że rząd w Sztokholmie oficjalnie uznał państwowość Palestyny (Michalak, 2017, s. 294).

Szwedzi, obserwując sytuację w Europie od początku XXI wieku, w tym rosnące tendencje radykalizacyjne wśród ludności muzułmańskiej, a w konsekwencji kolejne zamachy terrorystyczne (Madryt, Londyn, Paryż czy Bruksela), wyrażają coraz większą obawę przed zagrożeniem ze strony radykalnych organizacji muzułmańskich, których członkowie przybyli do Szwecji wraz z falą migrantów w 2015 roku. Przykładem ataków o podłożu islamofobicznym są m.in. ataki na muzułmańskie meczety z wykorzystaniem bomb domowej roboty czy wypuszczanie na ich dziedzińce świń, czyli zwierząt uznawanych przez muzułmanów za nieczyste (Elander i in., 2015, s. 22). Wzrastający niepokój spowodowany radyka- 
lizacją muzułmanów w Europie w wyniku wyobcowania i problemów z integracją z europejskim społeczeństwem oraz propaganda radykalnych organizacji terrorystycznych w połączeniu z działaniami mediów będą wpływać destrukcyjnie na wszelkie próby włączenia mniejszości muzułmańskiej w życie społeczne Szwecji (Kobieracka, 2016, s. 49).

\section{Bibliografia:}

Abdullahi, M., Hübinette, T. (2018). Swedish Muslims in Cooperation Network Alternative Report. Pobrane z: https://tbinternet.ohchr.org/Treaties/CERD/Shared\%20Documents/SWE/INT_CERD_NGO_SWE_30871_E.pdf.

Bevelander, P., Otterbeck, J. (2007). Young People's Attitudes towards Muslims in Sweden. Pobrane z: http://ftp.iza.org/dp2977.pdf.

Brljavac, B. (2017). Refugee Crisis in Europe: The Case Studies of Sweden and Slovakia. Journal of Liberty and International Affairs, 3, 91-107.

Cochan, E., Borevi, K., Mouritsen, P. (2017). A "Civic Turn" in Scandinavian Family Migration Policies? Comparing Denmark, Norway and Sweden. Pobrane z: https://pure.au.dk/portal/files/113867549/06_02_A_civic_turn_in_Scandinavian_family_migration_policies_2017.pdf.

Eidemiller, K.Y., Samylovskaya, E.A., Kudryavtseva, R.-E.A. (2018). Islamic Diffusion of Nordic Countries: Sweden. Pobrane z: https://iopscience.iop.org/article/10.1088/1755-1315/180/1/012005/pdf.

Elander, I., Fridolfsson, C., Gustavsson, E. (2015). Swedish Muslims and Secular Society: Faith-Based Engagement and Place. Islam and Christian-Muslim Relations, 26, 145-163. DOI: 10.1080/09596410.2015.1013324.

Eurostat. (2016). Pobrane z: https://ec.europa.eu/eurostat/documents/6049358/7005580/ Asylum\%2Bquarterly\%2Breport\%2B-\%2BQ4\%2B2015.pdf/7c7307b1-a816-439ba7d9-2d15e6e22e82.

Gromkowska-Melosik, A. (2013). Mniejszość muzułmańska w Szwecji: między ekstremistycznym izolacjonizmem a procesami reprodukcji ekonomicznej. Studia Edukacyjne, 26, 63-77.

Kobieracka, A. (2016). Między wielokulturowościa a integracją. Ewolucja polityki Szwecji w świetle zmieniajacych się wyzwań migracyjnych. Łódź: Wydawnictwo Ibidem.

Kosmynka, S. (2020). The Problem of Radical Salafism in Sweden in the Context of Terrorist Threats. Przeglad Europejski, 4, 117-130.

Larsson, G. (2007). Muslims in the EU: Cities Report. Pobrane z: https://www.opensocietyfoundations.org/uploads/a801911c-65ac-4a92-a902-10ab06ebb750/museucitiesswe_20080101_0.pdf.

Michalak, R. (2017). Szwedzki nurt islamosceptyzmu. Uzasadnienia postulatu deszariatyzacji. W: S. Dudra, R. Michalak, Ł. Młyńczyk (red.). Polityczne uwarunkowania religii - religijne uwarunkowania polityki (s. 287-306). Zielona Góra: Wydawnictwo Morpho. 
Mulinari, L.S. (2019). The Spectrum of Repression: Swedish Muslims' Experiences of Anti-terrorism Measures. Critical Criminology, 27(3), 451-466.

Sturup, J., Mondanib, H., Thevselius, P., Sarnecki, J., Edling, C. (2020). The Swedish Mujahideen: An Exploratory Study of 41 Swedish Foreign Fighters Deceased in Iraq and Syria. Studies in Conflict \& Terrorism, 43, 382-395.

Woźniak, M. (2012). Czy muzułmanie mogą być „lagom”? Różne oblicza islamu w Szwecji. W: M. Widy-Behiesse (red.). Islam w Europie. Bogactwo różnorodności czy źródto konfliktów? (s. 231-245). Warszawa: Wydawnictwo Akademickie Dialog.

Zawadzki, P.W. (2016). Szwedzka polityka imigracyjna. W: G. Firlit-Fesnak, Ł. Łotocki, P.W. Zawadzki (red.). Europejskie polityki imigracyjne. Stare dylematy, nowe wyzwania (s. 73-112). Warszawa: Zakład Migracji i Stosunków Etnicznych Instytutu Polityki Społecznej. Wydział Dziennikarstwa i Nauk Politycznych Uniwersytetu Warszawskiego. 